\title{
Balloon Brachytherapy
}

National Cancer Institute

\section{Source}

National Cancer Institute. Balloon Brachytherapy. NCI Thesaurus. Code C64385.

A therapeutic procedure involving the insertion of an inflatable balloon catheter filled with radioactive material into a resection cavity in order to deliver radiation to any remaining cancer cells in and around the tumor bed. 